\title{
HUBUNGAN TINGKAT KECERDASAN EMOSIONAL DAN KEMAMPUAN KOMUNIKASI DENGAN PROSES ADAPTASI MAHASISWA BARU DI AKADEMI KEPERAWATAN PANTIKOSALASURAKARTA
}

\author{
Endang Dwi Ningsih ${ }^{1}$, Fransisca Vita Febriana ${ }^{2}$
}

\begin{abstract}
Introduction: Adaptation is a changing process which is individual respond toward their environmental changing. Adaptive respond is totality respond of a person as the holistic creature that in adaptation process the time is needed and different on each other.

Purpose of the study: To determine the correlation of the emotional quotient level and the communiation ability in adaptation process on the new student at Panti Kosala Nursing Academy.

Subjects: On 103 new student at Panti Kosala Nursing Academy. Sampling technic used is purposif sampling, that the sampling for certain purpose.

Results:Multivariat test result by "Regresi Logistik Ganda" the value is Nagelkerke R Square $45,1 \%$

Conclusion : The emotional quotient level and the communication ability both have significant correlation that influence to adaptation process on the new student at Panti Kosala Nursing Academy, the test value is $45,1 \%$ and the rest is $54,9 \%$ influenced by other variable nonresearch.
\end{abstract}

Keywords: The emotional quotient level, Communication ability, adaptation process

\section{PENDAHULUAN}

Banyak orang beranggapan bahwa, peningkatan kualitas sumber daya manusia dalam mencapai suatu keberhasilan hanya semata-mata ditentukan oleh kecerdasan intelektual (IQ) saja. Namun pada dasarnya kunci keberhasilan dan kemajuan tidak hanya ditentukan oleh kecerdasan intelektual (IQ) saja, tetapi ditentukan juga oleh kecerdasan emosional (EQ) dan kecerdasan spiritual (SQ). Kecerdasan otak merupakan syarat minimal untuk meraih keberhasilan, sedangkan kecerdasan emosional merupakan syarat yang

menghantarkan seorang menuju puncak prestasi. Seseorang yang memiliki EQ rendah adalah orang yang buta hati dan buta nurani. (Sunaryo, 2014)
Menurut Chandra

(2010)

sebagaimana dikutip oleh Sunaryo (2014), kecerdasan emosional (EQ) adalah suatu bidang yang menyelidiki dan menggali cara manusia mempergunakan ketrampilan subjektif dan non kognitifnya agar dapat mengelola dan meningkatkan hubungan sosial dan kondisi kehidupan mereka.

Menurut Arista (2006) sebagaimana dikutip oleh Prawira (2013), Daniel Goleman mengatakan bahwa peran kecerdasan kognitif (IQ) yang menyokong kesuksesan hidup seseorang sekitar 20\%. Sedangkan yang $80 \%$ lainnya berupa faktorfaktor lain yang disebut kecerdasan emosional (EQ).

Menurut Goleman (2000) sebagaimana dikutip oleh Aunurrahman (2012), kecerdasan 
emosional (EQ) tidak dipengaruhi oleh faktor keturunan, merupakan hasil dari aktivitas individu dalam melatih fungsi-fungsi emosional diri sendiri atau oleh orang lain sehingga lebih merupakan hasil belajar. Kecerdasan emosional lebih banyak diperoleh melalui belajar dari pengalaman sendiri.

Manusia adalah makhluk sosial dan tindakan pertama dan paling penting, adalah tindakan sosial, suatu tindakan tepat saling menukar pengalaman, saling mengemukakan dan menerima pikiran, saling mengutarakan perasaan atau saling mengekspresikan, serta menyetujui suatu pendirian atau keyakinan. Oleh karena itu, maka di dalam tindakan sosial haruslah terdapat elemen-elemen umum yang samasama disetujui dan dipahami oleh sejumlah orang yang merupakan suatu masyarakat. Untuk menghubungkan sesama anggota masyarakat maka diperlukanlah komunikasi. (Tarigan, 2008)

Elemen-elemen yang terdapat dalam komunikasi adalah komunikator atau orang yang menyampaikan pesan, pesan atau ide atau informasi yang disampaikan, media atau sarana komunikasi, komunikan atau audiens, pihak yang menerima pesan, dan umpan balik atau respons dari komunikan terhadap pesan yang diterimanya. Sementara itu fungsi komunikasi adalah membangun konsep diri, eksistensi diri, kelangsungan hidup, memperoleh kebahagiaan, dan terhindar dari tekanan serta ketegangan. (Damayanti, 2013)

Tindak komunikasi adalah aktivitas pertukaran ide atau gagasan. Secara sederhana, tindak komunikasi dipahami sebagai kegiatan penyampaian dan penerimaan pesan atau ide dari satu pihak ke pihak lain, dengan tujuan untuk mencapai kesamaan pandangan atas ide yang dipertukarkan tersebut. Teknik berbicara perlu dan butuh sebuah ketrampilan berbicara efektif, serangkaian teknik berbicara yang mumpuni agar bisa melakukan itu semua, baik penyampaian pesan, mempengaruhi orang, memotivasi, mempersuasif dan lain sebagainya. (Damayanti, 2013)

Menurut Hidayat (2008), adaptasi merupakan suatu proses perubahan yang menyertai individu dalam berespon terhadap perubahan yang ada di lingkungan dan dapat mempengaruhi keutuhan tubuh baik secara fisiologis maupun psikologis yang akan menghasilkan perilaku adaptif. Respons adaptif merupakan suatu totalitas respons dari manusia sebagai makhluk holistik, yang memerlukan waktu dalam proses penyesuaian dan setiap orang akan berbeda dalam proses penyesuaian, adakalanya orang cepat dalam beradaptasi, namun adakalanya lambat dalam beradaptasi.

Manusia memiliki kemampuan beradaptasi dengan lingkungan yang tanpa mengandung risiko hingga lingkungan dengan risiko berat. Selain memiliki kemampuan beradaptasi dengan lingkungan, manusia juga mampu menyesuaikan diri kepada tekanan sosial di masyarakat. (Prawira, 2013)

$\begin{array}{llr}\text { Berdasarkan } & \text { hasil } & \text { studi } \\ \text { pendahuluan, } & \text { terdapat } & 140 \\ \text { mahasiswa baru di Akper } & \text { Panti }\end{array}$ Kosala Surakarta. Hasil wawancara awal dengan beberapa mahasiswa baru, mereka masih merasakan sulit beradaptasi karena berada di tempat yang baru, dengan suasana baru, dan lingkup materi kuliah yang baru, sehingga memunculkan beberapa masalah di dalam proses adaptasi atau penyesuaian dengan lingkungan termasuk di dalamnya berkomunikasi. Bahkan sebagian yang ditemui pada studi awal penelitian merasakan bingung 
bahkan bertanya apa tidak cocok kuliah di keperawatan. Selama ini belum pernah diteliti tentang tingkat kemampuan emosional atau yang biasa disebut kecerdasan emosional dan kemampuan komunikasi dalam proses adaptasi pada mahasiswa di lingkungan kampus.

Berdasarkan latar belakang masalah di atas, penulis tertarik untuk melakukan penelitian tentang: Hubungan Tingkat Kecerdasan Emosional dan Kemampuan Komunikasi dengan Proses Adaptasi Mahasiswa Baru di Akademi Keperawatan Panti Kosala Surakarta.

\section{TUJUAN PENELITIAN}

Tujuan umum adalah untuk mengetahui Hubungan tingkat kecerdasan emosional dan kemampuan komunikasi dengan proses adaptasi mahasiswa baru di Akademi Keperawatan Panti Kosala Surakarta.

Adapun tujuan khusus dari penelitian ini adalah :

1. Mengetahui tingkat kecerdasan emosional (EQ) pada mahasiswa baru di Akademi Keperawatan Panti Kosala Surakarta.

2. Mengetahui kemampuan komunikasi pada mahasiswa baru di Akademi Keperawatan Panti Kosala Surakarta

3. Mengetahui kemampuan adaptasi mahasiswa baru di Akademi Keperawatan Panti Kosala Surakarta.

4. Mengetahui hubungan tingkat kecerdasan emosional dengan proses adaptasi mahasiswa baru di Akademi Keperawatan Panti Kosala Surakarta.

5. Mengetahui hubungan kemampuan komunikasi dengan proses adaptasi mahasiswa baru di Akademi Keperawatan Panti Kosala Surakarta.

\section{DESAIN PENELITIAN}

Desain penelitian atau disebut juga rancangan penelitian ditetapkan dengan tujuan agar penelitian dapat dilakukan dengan efektif dan efisien. Penelitian ini merupakan penelitian analitik dengan desain penelitian korelasi dan pendekatan cross sectional. Penelitian kolerasi bertujuan untuk mengungkapkan hubungan korelatif antar variabel. Sedangkan desain cross sectional merupakan rancangan penelitian yang berukuran atau pengamatannya dilakukan secara simultan pada suatu saat (sekali waktu). (Hidayat, 2008).

\section{POPULASI, SAMPEL, DAN TEHNIK SAMPLING}

Menurut Sekaran (2006), populasi (population) adalah mengacu pada keseluruhan kelompok orang, kejadian atau hal minat yang ingin peneliti investigasi. Populasi adalah merupakan seluruh subyek atau objek dengan karakteristik tertentu yang telah diteliti. Bukan hanya objek atau subjek yang dipelajari saja tetapi seluruh karakteristik atau sifat yang dimiliki subjek atau objek tersebut.(Hidayat, 2009) Adapun yang menjadi populasi dalam penelitian ini adalah mahasiswa baru Akademi Keperawatan Panti Kosala Surakarta yang berjumlah 140 orang.

Sampel merupakan bagian populasi yang telah diteliti atau sebagian jumlah dari karakteristik yang dimiliki oleh populasi. (Hidayat, 2008) Sampel dalam penelitian ini diambil berdasarkan kriteria yang meliputi:

1. Kriteria inklusi merupakan kriteria dimana subjek penelitian yang memenuhi syarat sebagai sampel. Adapun kriteria inklusi pada penelitian ini adalah : mahasiswa baru Akper Panti Kosala Surakarta dan yang bersedia menjadi responden. 
2. Kriteria eksklusi adalah kriteria dimana subjek penelitian tidak dapat mewakili sampel karena tidak memenuhi syarat sebagai sampel penelitian yang penyebabnya antara lain adalah adanya hambatan etis, menolak memungkinkan untuk dilakukan penelitian. Adapun kriteria eksklusi dalam penelitian ini meliputi : mahasiswa baru yang tidak bersedia menjadi responden dan mahasiswa tingkat II dan III Akper Panti Kosala Surakarta

Dalam penelitian ini dengan jumlah populasi sebanyak 140 orang maka berdasarkan tabel krecjie, diperoleh sampel sebesar 103 orang

Menurut Hidayat (2008), teknik sampling merupakan suatu proses seleksi sampel yang digunakan dalam penelitian dari populasi yang ada, sehingga jumlah sampel telah mewakili keseluruhan populasi yang ada.

Dalam penelitian ini, peneliti menggunakan teknik non probability sampling, yaitu dengan sampling purposif yaitu cara pengambilan sampel untuk tujuan tertentu. (Hidayat, 2009)

\section{HASIL PENELITIAN}

Di bawah ini akan dipaparkan karakteristik responden berdasarkan jenis kelamin, agama dan daerah asal mahasiswa adalah sebagai berikut :

1. Karakteristik Responden

a. Berdasarkan jenis kelamin

\begin{tabular}{ccc}
\multicolumn{3}{c}{ Tabel 1 } \\
\hline Jenis Kelamin & $\mathrm{f}$ & $\%$ \\
\hline Laki - Laki & 20 & 19 \\
\hline Perempuan & 83 & 81 \\
\hline Jumlah & 103 & 100 \\
\hline
\end{tabular}

Dari tabel di atas diperoleh informasi bahwa sebagian besar responden berjenis kelamin perempuan berjumlah 83 orang $(81 \%)$ dan jumlah responden paling sedikit berjenis kelamin laki-laki berjumlah 20 orang ( $19 \%$ ).

b. Berdasarkan agama

Tabel 2

\begin{tabular}{ccc}
\hline Agama & $f$ & $\%$ \\
\hline Islam & 78 & 76 \\
\hline $\begin{array}{l}\text { Kristen } \\
\text { Katolik }\end{array}$ & 23 & 23 \\
\hline Hindu & 1 & 1 \\
\hline Jumlah & 103 & 100 \\
\hline
\end{tabular}

Dari tabel di atas diperoleh informasi bahwa sebagian besar responden beragama Islam berjumlah 78 orang $(76 \%)$ dan jumlah responden beragama Kristen Katolik berjumlah 23 orang ( $23 \%$ ) serta responden yang beragama Hindu berjumlah paling sedikit yaitu 1 orang $(1 \%)$.

c. Berdasarkan Usia

Tabel 3

\begin{tabular}{ccc}
\hline Usia & $\mathrm{f}$ & $\%$ \\
\hline 17 tahun & 9 & 9 \\
\hline 18 tahun & 38 & 37 \\
\hline 19 tahun & 48 & 46 \\
\hline 20 tahun & 7 & 7 \\
\hline 21 tahun & 1 & 1 \\
\hline Jumlah & 103 & 100 \\
\hline
\end{tabular}

Dari tabel di atas diperoleh informasi bahwa sebagian besar responden berusia 19 tahun yaitu 48 orang (46\%) dan jumlah responden paling sedikit berusia 21 tahun yaitu 1 orang ( $1 \%)$. 
d. Berdasarkan daerah asal

Tabel 4

\begin{tabular}{ccc}
\hline Daerah Asal & $\mathrm{f}$ & $\%$ \\
\hline Dalam Kota & 35 & 34 \\
\hline Luar Kota & 68 & 66 \\
\hline Jumlah & 103 & 100 \\
\hline
\end{tabular}

Dari tabel di atas diperoleh informasi bahwa daerah asal responden adalah dalam kota berjumlah 35 orang (34 \%) dan luar kota berjumlah 68 orang (66 \%).

2. Hasil Penelitian

a. Variabel tingkat kecerdasan emosional.

Tabel 5

\begin{tabular}{ccc}
\hline $\begin{array}{c}\text { Tingkat } \\
\text { kecerdasan } \\
\text { emosional }\end{array}$ & $f$ & $\%$ \\
\hline Tinggi & 96 & 93 \\
\hline Rendah & 7 & 7 \\
\hline Jumlah & 103 & 100 \\
\hline
\end{tabular}

Dari tabel di atas ditemukan frekuensi paling banyak pada tingkat kecerdasan emosional tinggi yaitu 96 responden (93\%), sedangkan frekuensi paling sedikit pada tingkat kecerdasan emosional rendah yaitu 7 responden $(7 \%)$

b. Variabel kemampuan komunikasi

Tabel 6

\begin{tabular}{ccc}
\hline $\begin{array}{c}\text { Kemampuan } \\
\text { Komunikasi }\end{array}$ & $\mathrm{f}$ & $\%$ \\
\hline Tinggi & 94 & $91 \%$ \\
\hline Rendah & 9 & $9 \%$ \\
\hline Jumlah & 103 & $100 \%$ \\
\hline
\end{tabular}

Dari tabel di atas ditemukan frekuensi paling banyak pada kemampuan komunikasi kategori tinggi yaitu 94 responden ( $91 \%)$, sedangkan frekuensi paling sedikit pada kemampuan komunikasi kategori rendah yaitu 9 responden (9\%)

c. Variabel proses adaptasi.

Tabel 7

\begin{tabular}{lcc}
\hline \multicolumn{1}{c}{ Proses } & $f$ & $\%$ \\
\multicolumn{1}{c}{ Adaptasi } & $f$ & $78 \%$ \\
\hline $\begin{array}{l}\text { Mampu } \\
\text { beradaptasi }\end{array}$ & 80 & $22 \%$ \\
\hline $\begin{array}{l}\text { Kurang } \\
\text { mampu } \\
\text { beradaptasi }\end{array}$ & 23 & \\
\hline Jumlah & 103 & $100 \%$ \\
\hline
\end{tabular}

Dari tabel di atas ditemukan frekuensi paling banyak pada poses adaptasi kategori mampu yaitu 80 responden ( $78 \%$ ), sedangkan frekuensi paling sedikit pada proses adaptasi kategori kurang yaitu 23 responden ( $22 \%$ )

d. Hubungan tingkat kecerdasan emosional dengan proses adaptasi.

Tabel 8

\begin{tabular}{cccc}
\hline Tingkat & \multicolumn{3}{c}{ Proses Adaptasi } \\
\cline { 2 - 4 } $\begin{array}{c}\text { Kecerda } \\
\text { san }\end{array}$ & Mampu & Kurang & Jumlah \\
\cline { 2 - 4 } Tinggi & 79 & 17 & 96 \\
\hline Rendah & 1 & 6 & 7 \\
\hline Jumlah & 80 & 23 & 103 \\
\hline
\end{tabular}

Berdasarkan tabel di atas dapat dilihat bahwa :

1) Terdapat responden yang memiliki tingkat kecerdasan emosional tinggi 96 orang, 79 orang mampu beradaptasi dan 17 orang kurang mampu beradaptasi.

2) Terdapat responden yang memiliki tingkat kecerdasan emosional rendah 7 orang, 1 orang mampu beradaptasi dan 6 orang kurang mampu beradaptasi. 
Berdasarkan hasil uji dengan menggunakan Chi Square menggunakan program SPSS for windows seri 22 dengan $\alpha$ $=5 \%(0.05)$ diperoleh $p$ sebesar 0,000 sehingga $p<$ 0.05 , yang berarti hipotesa diterima maka dapat ditarik kesimpulan bahwa ada hubungan tingkat kecerdasan emosional dengan proses adaptasi mahasiswa baru di Akademi Keperawatan Panti Kosala Surakarta.

e. Hubungan kemampuan komunikasi dengan proses adaptasi

Tabel 9

\begin{tabular}{ll}
\hline Komu & Proses Adaptasi \\
nikasi & Mampu Kurang Jumlah
\end{tabular}

\begin{tabular}{cccc}
\hline Tinggi & 78 & 16 & 94 \\
\hline Rendah & 2 & 7 & 9 \\
\hline Jumlah & 80 & 23 & 103 \\
\hline
\end{tabular}

Berdasarkan tabel di atas dapat dilihat bahwa :

1) Terdapat responden yang memiliki kemampuan komunikasi kategori tinggi 94 orang, 78 orang mampu beradaptasi dan 16 orang kurang mampu beradaptasi.

2) Terdapat responden yang memiliki kemampuan komunikasi kategori rendah 9 orang, dan 2 orang mampu beradaptasi dan 7 orang kurang mampu beradaptasi.

Berdasarkan hasil uji dengan menggunakan Chi Square menggunakan program SPSS for windows seri 22 dengan $\alpha$ $=5 \%(0.05)$ diperoleh $\mathrm{p}$ sebesar 0,000 sehingga $p<$
0.05, yang berarti hipotesa diterima maka dapat ditarik kesimpulan bahwa ada hubungan kemampuan komunikasi dengan proses adaptasi mahasiswa baru di Akademi Keperawatan Panti Kosala Surakarta.

f. Hubungan tingkat kecerdasan emosional dan kemampuan komunikasi dengan proses adaptasi

Tabel 10

\begin{tabular}{lcc}
\hline $\begin{array}{l}\text { Variabel } \\
\text { Independen }\end{array}$ & OR & $\mathrm{P}$ \\
\hline $\begin{array}{c}\text { Tingkat } \\
\text { Kecerdasan } \\
\text { emosional }\end{array}$ & 8,64 & 0,999 \\
\hline $\begin{array}{c}\text { Kemampuan } \\
\text { Komunikasi }\end{array}$ & 21,00 & 0,001 \\
\hline Nagelkerke R Square 45,1\% \\
\hline
\end{tabular}

Berdasarkan tabel di atas menunjukkan :

1) Adanya hubungan yang positif dan tidak signifikan antara tingkat kecerdasan emosional dengan proses adaptasi mahasiswa baru. Mahasiswa baru yang memiliki tingkat kecerdasan emosional tinggi kemungkinan mampu beradaptasi 8,64 kali lebih besar dari pada mahasiswa yang memiliki tingkat kecerdasan emosional rendah. $(\mathrm{OR}=8,64 ; \mathrm{p}=$ 0,999)

2) Adanya hubungan yang positif dan signifikan antara kemampuan komunikasi dengan proses adaptasi mahasiswa baru. Mahasiswa baru yang memiliki kemampuan 


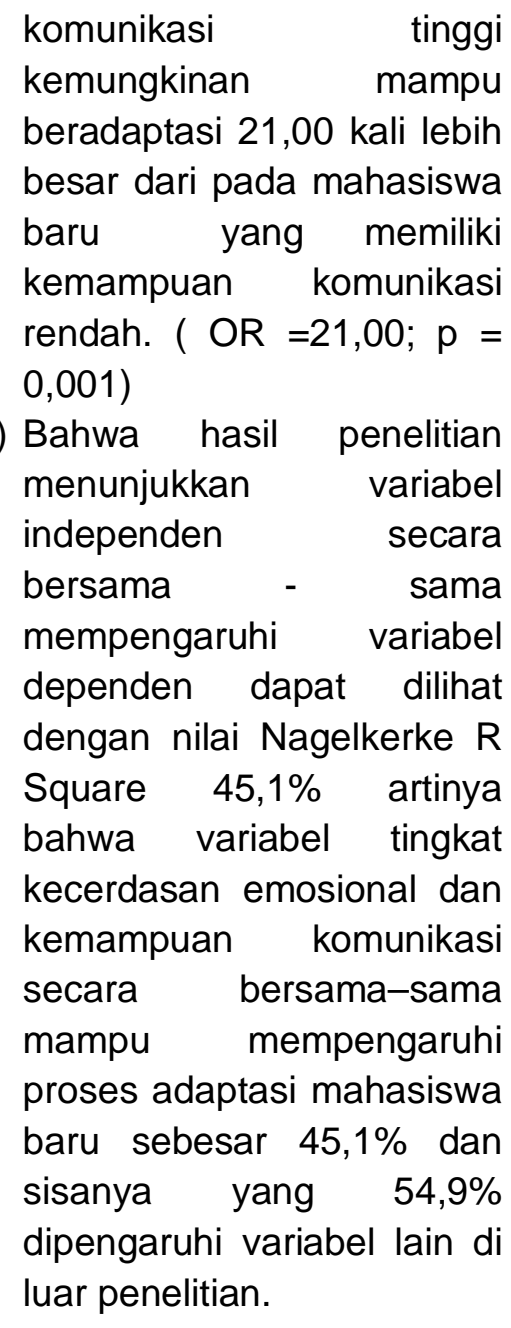

\section{PEMBAHASAN}

1. Hubungan Tingkat Kecerdasan Emosional dengan Proses Adaptasi Mahasiswa Baru

Berdasarkan tabel 5 dapat dilihat bahwa sebagian besar tingkat kecerdasan emosional mahasiswa baru pada kategori tinggi yakni 93\%. Kecerdasan emosional sebagaimana yang dikutip oleh Prawira (2013), menggambarkan sejumlah keterampilan yang berhubungan dengan keakuratan penilaian tentang emosi diri sendiri dan orang lain, serta kemampuan mengelola perasaan untuk memotivasi, merencanakan, dan meraih tujuan kehidupan.
Sebagaimana yang dikutip Aunurrahman (2012), Goleman menggambarkan beberapa ciri kecerdasan emosional yang terdapat pada diri seseorang berupa :

a. Kemampuan memotivasi diri sendiri merupakan kemampuan internal pada diri seseorang berupa kekuatan menjadi suatu energi yang mendorong seseorang untuk mampu menggerakkan potensi-potensi fisik dan psikologis atau mental dalam melakukan aktivitas tertentu sehingga mampu mencapai keberhasilan yang diharapkan.

b. Ketahanan menghadapi frustasi akan mendorong anak untuk memiliki daya tahan yang lebih tinggi bilamana suatu saat ia dihadapkan pada persoalan-persoalan yang lebih kompleks dan rumit. Bilamana keadaan yang buruk akan terjadi, maka anak diharapkan dapat mengendalikan diri, menata emosinya sehingga tidak memerlukan tindakan-tindakan yang dapat merugikan dirinya sendiri.

c. Kemampuan mengendalikan dorongan hati dan tidak melebih-lebihkan kesenangan, kematangan berpikir anak, tidak sekedar ditunjukkan oleh kemampuan nalar, akan tetapi justru lebih banyak ditunjukkan melalui isyarat-isyarat emosional. Faktor empati merupakan hal penting yang harus dikembangkan, karena dengan kemampuan berempati seseorang akan 
dapat mengetahui bagaimana perasaan orang lain.

d. Kemampuan menjaga suasana hati dan menjaga agar beban stres tidak melumpuhkan kemampuan berpikir, berempati, dan berdoa hal ini terkait dengan kemampuan mengatasi masalah, karena seseorang yang telah mampu mengatasi masalah-masalah yang dihadapi akan lebih dewasa dalam menghadapi persoalanpersoalan yang lebih baik. Seseorang yang memiliki kecerdasan emosional akan dapat melihat persoalanpersoalan secara jernih, berupaya mengatasi persoalan-persoalan tersebut dan berharap adanya kekuatan penolong Yang Maha Pencipta.

Dari uraian di atas maka bila dihubungkan dengan proses adaptasi mahasiswa baru, pada tabel 8 dipaparkan bahwa dari 93\% responden yakni 96 orang, 79 orang mampu beradaptasi dan 17 orang kurang mampu beradaptasi maka menunjukkan bahwa seseorang yang memiliki tingkat kecerdasan emosional yang tinggi akan mampu beradaptasi dengan baik.

Hal demikian dikuatkan dengan
hasil analisis bivariat
menggunakan uji Chi Square
didapatkan hasil $\mathrm{p}$ sebesar 0,000
sehingga $\mathrm{p}<0.05$, yang berarti
bahwa ada hubungan antara
tingkat kecerdasan emosional
dengan proses adaptasi

mahasiswa baru di Akademi Keperawatan Panti Kosala Surakarta. Sebagaimana yang dikutip oleh Aunurrahman (2012) bahwa kecerdasan emosional tidak dipengaruhi oleh faktor keturunan, tetapi banyak diperoleh melalui belajar dari pengalaman sendiri, hal ini sesuai karakteristik usia responden $48 \%$ berusia 19 tahun, dari usia tersebut menunjukkan bahwa mahasiswa baru sudah memiliki pengalaman dari proses pembelajaran yang telah dialami sehingga mampu beradaptasi dengan lingkungan baru.

Sebagaimana yang dikutip oleh Suseno (2009), bahwa terdapat perbedaan antara tingkat kecerdasan emosional pria dan wanita, untuk wanita dapat bersikap tegas, mampu mengungkapkan perasaannya secara langsung, memandang dirinya secara positif, mudah bergaul, bila hal ini dikaitkan dengan karakteristik responden yang paling banyak wanita sebesar $81 \%$ maka sesuai bila tingkat kecerdasan emosional paling banyak pada kategori tinggi sehingga mahasiswa mampu beradaptasi dengan baik.

Hasil penelitian ini sesuai dengan penelitian Septiyaningtyas (2014) yang meneliti tentang pengaruh kecerdasan emosional terhadap penyesuaian diri siswa SD kelas V Segugus Puren Condongcatur Depok Sleman Yogjakarta, dimana didapatkan hasil terdapat hubungan yang positif dan signifikan antara kecerdasan 
emosional dan penyesuaian diri dan variabel kecerdasan emosional memberikan sumbangan sebesar $42 \%$ terhadap variabel penyesuaian diri dan sisanya $58 \%$ dipengaruhi variabel lain di luar penelitian.

2. Hubungan

Kemampuan

Komunikasi dengan Proses

Adaptasi Mahasiswa Baru

Berdasarkan tabel 9 dapat dilihat bahwa sebagian besar tingkat kemampuan komunikasi mahasiswa baru pada kategori tinggi yakni 91\%. Komunikasi sebagaimana yang dikutip oleh Damayanti (2013), bahwa fungsi komunikasi adalah membangun konsep diri, eksistensi diri, kelangsungan hidup, memperoleh kebahagiaan dan terhindar dari tekanan serta ketegangan maka perlu adanya tindak komunikasi yang dapat dipahami antara pihak satu ke pihak lain dengan tujuan memperoleh kesamaan pandangan atas ide yang dipertukarkan. Maka bila kemampuan komunikasi mahasiswa baru lebih banyak pada kategori tinggi hal ini akan lebih mempermudah mahasiswa dalam menjalin komunikasi dengan teman, senior, dan dosen, dengan kemampuan komunikasi yang baik seseorang akan mumpuni dalam melakukan penyampaian pesan, mempengaruhi orang, memotivasi, mempersuasif sebagaimana yang disampaikan oleh Damayanti (2013)
Dari uraian di atas maka bila dihubungkan dengan proses adaptasi mahasiswa baru, pada tabel 9 dipaparkan bahwa dari $91 \%$ responden yakni 94 orang, 78 orang mampu beradaptasi dan 16 orang kurang mampu beradaptasi maka menunjukkan bahwa seseorang yang memiliki kemampuan komunikasi yang tinggi akan mampu beradaptasi dengan baik.

Hal demikian dikuatkan dengan hasil analisis bivariat menggunakan uji Chi Square didapatkan hasil $p$ sebesar 0,000 sehingga $p<0.05$, yang berarti bahwa ada hubungan antara kemampuan komunikasi dengan proses adaptasi mahasiswa baru di Akademi Keperawatan Panti Kosala Surakarta. Sebagaimana yang disampaikan oleh Nasir, et al., (2009) beberapa faktor yang mempengaruhi proses komunikasi adalah perkembangan, persepsi, nilai, latar belakang sosial budaya, emosi, jenis kelamin, pengetahuan, peran dan hubungan serta lingkungan. Maka dengan hasil uji bivariat terdapat hubungan antara komunikasi dan adaptasi mahasiswa baru di Akademi Keperawatan Panti Kosala menunjukkan bahwa faktor- faktor yang mempengaruhi komunikasi sebagaimana yang disampaikan oleh Nasir, et al., ( 2009) dimiliki oleh mahasiswa untuk melakukan adaptasi di Akademi keperawatan Panti Kosala Surakarta. 
3. Hubungan antara tingkat kecerdasan emosional dan kemampuan komunikasi dengan proses adaptasi mahasiswa baru di Akademi Keperawatan Panti Kosala Surakarta.

Hasil penelitian menunjukkan variabel independen secara bersama-sama mempengaruhi variabel dependen dapat dilihat dari nilai Nagelkerke $R$ Square $45,1 \%$ yaitu dengan model regresi logistik ganda, variabel independen yang dimasukkan dalam model yaitu tingkat kecerdasan emosional dan kemampuan komunikasi secara bersamaan mampu menjelaskan variabel dependen yaitu proses adaptasi mahasiswa baru, maka dapat disimpulkan bahwa secara bersama - sama variabel independen yaitu tingkat kecerdasan emosional dan kemampuan komunikasi berpengaruh terhadap variabel dependen yaitu proses adaptasi mahasiswa baru.

Dari tabel 7. di atas menunjukkan proses adaptasi yang baik pada mahasiswa baru yakni $78 \%$ berarti mahasiswa baru memiliki perilaku adaptif. Menurut Hidayat (2008), proses adaptasi merupakan suatu proses perubahan yang menyertai individu dalam berespons terhadap perubahan yang ada di lingkungan dan dapat mempengaruhi keutuhan tubuh baik secata fisiologis maupun psikologis yang akan menghasilkan perilaku adaptif . Demikian pula yang dikutip oleh
Sunaryo (2014), adaptasi adalah usaha atau perilaku yang tujuannya mengatasi kesulitan dan hambatan, dengan penyesuaian diri maka akan terjadi perubahan anatomi, psikologi dan fisiologi dalam diri seseorang yang terjadi sebagai reaksi terhadap stres. Maka jika hasil adaptasi mahasiswa baru baik (mampu adaptasi) memberi gambaran bahwa mahasiswa baru mampu mengatasi kesulitan dan hambatan di lingkungan yang baru yaitu di Akademi Keperawatan Panti Kosala Surakarta.

Penyesuaian diri sebagai suatu proses melibatkan manusia sepanjang hidupnya mulai dari anak-anak sampai dewasa bahkan sampai menginjak lanjut usia, maka dibutuhkan rasa empati, kepedulian, kejujuran, integritas dan cara pemecahan masalah yang merupakan lingkup dari kecerdasan emosional dan juga dibutuhkan komponen komunikasi yang merupakan rangkaian proses pengalihan informasi dan pertukaran makna antar pribadi. Dengan demikian tingkat kecerdasan emosional dan kemampuan komunikasi merupakan faktor yang mempengaruhi proses adaptasi mahasiswa baru di Akademi Keperawatan Panti Kosala Surakarta.

\section{KESIMPULAN}

Dari hasil penelitian yang berjudul Hubungan Tingkat Kecerdasan Emosional dan Kemampuan Komunikasi dengan Proses Adaptasi 
mahasiswa Baru di Akademi Keperawatan Panti Kosala Surakarta dapat diperoleh kesimpulan sebagai berikut :

1. Ditemukan frekuensi paling banyak pada tingkat kecerdasan emosional tinggi yaitu 96 responden $(93 \%)$, sedangkan frekuensi paling sedikit pada tingkat kecerdasan emosional rendah yaitu 7 responden (7\%).

2. Ditemukan frekuensi paling banyak pada kemampuan komunikasi kategori tinggi yaitu 94 responden (91\%), sedangkan frekuensi paling sedikit pada kemampuan komunikasi kategori rendah yaitu 9 responden ( $9 \%$ ).

3. Ditemukan frekuensi paling banyak pada proses adaptasi kategori mampu yaitu 80 responden ( $78 \%$ ), sedangkan frekuensi paling sedikit pada proses adaptasi kategori kurang yaitu 23 responden (22\%).

4. Berdasarkan hasil uji dengan menggunakan Chi Square menggunakan program SPSS for windows seri 22 dengan $\alpha=5 \%$ (0.05) diperoleh $p$ sebesar 0,000 sehingga $p<0.05$, yang berarti hipotesa diterima maka dapat ditarik kesimpulan bahwa ada hubungan tingkat kecerdasan emosional dengan proses adaptasi mahasiswa baru di Akademi Keperawatan Panti Kosala Surakarta.

5. Berdasarkan hasil uji dengan menggunakan Chi Square menggunakan program SPSS for windows seri 22 dengan $\alpha=5 \%$ (0.05) diperoleh $p$ sebesar 0,000 sehingga $p<0.05$, yang berarti hipotesa diterima maka dapat ditarik kesimpulan bahwa ada hubungan kemampuan komunikasi dengan proses adaptasi mahasiswa baru di Akademi Keperawatan Panti Kosala Surakarta.

6. Berdasarkan uji Multivariat menunjukkan variabel independen secara bersama sama mempengaruhi variabel dependen dapat dilihat dengan nilai Nagelkerke R Square $45,1 \%$ artinya bahwa variabel tingkat kecerdasan emosional dan kemampuan komunikasi secara bersama-sama mampu mempengaruhi proses adaptasi mahasiswa baru sebesar $45,1 \%$ dan sisanya yang $54,9 \%$ dipengaruhi variabel lain di luar penelitian. Jadi terdapat hubungan antara tingkat kecerdasan emosional dan kemampuan komunikasi dengan proses adaptasi mahasiswa baru Akademi Keperawatan Panti Kosala Surakarta.

\section{SARAN}

1. Sesuai hasil penelitian bahwa antara tingkat kecerdasan emosional dan kemampuan komunikasi dengan proses adaptasi ada hubungan, maka hasil penelitian ini dapat memberi pemahaman bagi civitas akademika khususnya mahasiswa dan pengelola pendidikan dapat memberikan dan menerapkan proses adaptasi di lingkungan pendidikan melalui pengembangan tingkat kecerdasan emosional dan peningkatan kemampuan komunikasi agar mahasiswa memiliki/menunjukkan perilaku adaptif di lingkungan kampus sehingga bermanfaat dalam pencapaian pembelajaran. 
2. Bagi Peneliti selanjutnya diharapkan dapat digunakan sebagai dasar untuk penelitian selanjutnya tentang proses adaptasi dengan variabel lain.

\section{KETERBATASAN}

Penelitian ini memiliki keterbatasan antara lain :

1. Penelitian yang dilakukan hanya mengambil populasi pada mahasiswa baru Akademi Keperawatan Panti Kosala Surakarta sehingga hasil penelitian tidak dapat digeneralisasi.

2. Instrumen penelitian yang digunakan kepada responden hanya melalui pengisian kuesioner dan tidak dilakukan wawancara langsung sehingga peneliti sulit mengendalikan responden.

\section{DAFTAR PUSTAKA}

Aunurrahman. 2012. Belajar dan Pembelajaran. Alfabeta, Bandung.

Asmani, Jamal. 2011. Mamur. Pembelajaran Aktif, Kreatif, Efektif dan Menyenangkan. Diva Pres, Yogjakarta.

Damayanti, D. 2013. Satu Jam Mahir Public Speaking Untuk Guru dan Dosen. Pinang Merah Publisher, Yogjakarta.

Dahlan, M. Sopiyudin. 2012. Statistik Untuk Kedokteran dan Kesehatan. Salemba Medika, Jakarta.

Fajar, Ibnu, et al. 2009. Statistika untuk Praktisi Kesehatan. Graha Ilmu, Yogyakarta.
Goleman, Daniel. 2007. Kecerdasan Emosional. Alih bahasa $\mathrm{T}$. Hermaya. Gramedia Pustaka Utama, Jakarta.

Hidayat, A. Aziz Alimul. 2008. Pengantar Konsep Dasar Keperawatan. Edisi II. Salemba Medika, Jakarta.

2009. Riset Keperawatan dan Teknik Penulisan IImiah. Edisi II. Salemba Medika, Jakarta.

2009. Metode Penelitian Keperawatan dan Teknik Analisa Data. Salemba Medika, Jakarta.

Liliweri, Alo. 2007. Dasar - dasar Komunikasi Kesehatan. Pustaka Pelajar, Jakarta.

Nasir, et al.,. 2009. Komunikasi Dalam Keperawatan: Teori dan Aplikasi. Salemba Medika, Jakarta.

Prawira, Purwa Atmaja. 2013. Psikologi Pendidikan dalam Perspektif Baru:: Ar-Ruzz Media, Yogjakarta.

Sekaran, Uma. 2006. Research Methods For Busines : Metodologi Penelitian untuk Bisnis. Salemba Empat, Jakarta.

Sunaryo. 2014. Psikologi untuk Keperawatan. Edisi II. EGC, Jakarta.

Suseno, Tutu April A. 2009. EQ Orangtua vs EQ Anak Orangtua Pintar, Anak pun Pintar. Locus, Jogjakarta.

Suyanto. 2011. Metodologi dan Aplikasi Penelitian Keperawatan. Nuha Medika, Yogyakarta. 
Tamsuri, Anas. 2006. Komunikasi dalam Keperawatan. EGC, Jakarta.

Zen, Pribadi. 2013. Panduan Komunikasi Efektif untuk Bekal Keperawatan Profesional. DMedika, Yogyakarta.

Septiyaningtyas, Retno. 2014. "Pengaruh Kecerdasan Emosi Terhadap Penyesuaian Sosial Siswa Kelas V Sd Se-Gugus Puren Condongcatur Depok Sleman Yogyakarta Tahun Ajaran 2013/2014". URL: http://www.eprints.uny.ac.id/14 423. Diakses 06 Oktober 2015
Setyarini, Elizabeth Ari. 2012. "Hubungan Komponen Dasar Kecerdasan Emosional Dengan Proses Adaptasi Mahasiswa Tinggal di Asrama Stikes Santo Borromeus di Kota Baru Parahyangan". URL:

http://www.prosiding.lppm.unis ba.ac.id/index.php/ so. Diakses 06 Oktober 2015.

1 Dosen AKPER Panti Kosala Surakarta

2 Mahasiswa AKPER Panti Kosala Surakarta 